\title{
Pergeseran Representasi Feminitas dalam Film Animasi Disney Princess
}

\author{
Naurissa Biasini \\ Program Studi Ilmu Komunikasi, Universitas Pembangunan Jaya \\ naurissa.biasini@upj.ac.id
}

\begin{abstract}
Disney Princess animated films not only show entertainment for the audience but also the representation of femininity that can affect the mindset of the viewers, especially children. The representation should evolve in line with the global feminist movement in order for the audience to have a realistic description of the condition of women in every era. Research is needed to determine whether the transition is in line with the development of feminism waves and theories. This study uses a critical approach with Sara Mills' critical discourse analysis research method, using feminist theories and concepts of femininity as a reference. The data collection was completed using primary data, specifically observations and interviews, as well as secondary data from the study of literature and documentation. Observations were accomplished by watching 11 Disney Princess animated films while interviews were conducted with the Disney directors, feminist activists, and three Disney Princess enthusiasts. The final analysis shows that the transition in the representation of femininity in Disney Princess animated films indicates inequalities and emphasizes the rebellious side of woman.
\end{abstract}

Keywords: Animated Films, Disney Princess, Feminism, Femininity, Representation, Inequalities

\begin{abstract}
Abstrak : Film animasi Disney Princess tidak hanya menampilkan hiburan bagi penontonnya namun juga representasi feminitas yang dapat mempengaruhi pola pikir penontonnya terutama anak-anak. Representasi tersebut seharusnya berkembang sejalan dengan perkembangan gelombang feminisme di dunia agar penonton memiliki gambaran nyata mengenai kondisi perempuan di setiap era. Karena itu diperlukan penelitian untuk mengetahui apakah pergeseran yang terjadi sejalan dengan perkembangan teori dan gelombang feminisme. Penelitian ini menggunakan pendekatan kritis dengan metode penelitian analisis wacana kritis Sara Mills. Pengumpulan data penelitian dilakukan dengan data primer, yaitu observasi dan wawancara, serta data sekunder berupa studi kepustakaan dan dokumentasi. Observasi dilakukan dengan menonton 11 film animasi Disney Princess sedangkan wawancara dilakukan kepada sutradara Disney, aktivis feminis, dan tiga orang penonton anime Disney Princess. Hasil analisa menunjukkan bahwa ada pergeseran representasi feminitas yang terjadi dalam film animasi Disney Princess, meskipun menunjukkan ketidaksetaraan dan justru menampilkan sisi pemberontakan dalam diri perempuan.
\end{abstract}

Kata kunci: Film Animasi, Disney Princess, Representasi, Feminisme, Feminitas, Ketidaksetaraan

\section{PENDAHULUAN}

Sebagai salah satu media dalam komunikasi massa, film juga memiliki fungsi seperti media massa lainnya yaitu edukatif, informatif, persuasif, dan juga kontrol sosial meskipun tujuan utama khalayak dalam menonton film adalah ingin memperoleh hiburan (Ardianto, Komala and Karlinah 2007:145). Meskipun begitu McQuails (2010:32) menyatakan bahwa dalam kenyataannya, film tidak hanya memiliki fungsi hiburan 
yang dominan, namun juga sering kali menampilkan unsur mendidik, dan memiliki kecenderungan propaganda. Selain itu film pun lebih rentan terhadap campur tangan luar dan tunduk pada tekanan kaum konformis karena ada begitu banyak modal yang dipertaruhkan. Pernyataan ini menunjukkan bahwa film tidak hanya sekedar bentuk media yang menghibur namun juga ada kecenderungan penyampaian pesan yang diinginkan oleh pembuat film.

Seiring dengan perkembangannya, film semakin tersegmentasi dengan munculnya berbagai jenis dan genre film. Di awal kemunculannya, film diproduksi tanpa narasi yang dikenal sebagai film bisu. Kemudian pada akhir tahun 1920an Dominick (2011:206) menyatakan barulah muncul film bicara pertama. Sejak saat itu jenis-jenis film pun semakin beragam mulai dari film drama keluarga, film perang, film aksi, hingga film untuk anakanak. Salah satu bentuk perkembangan film animasi di Amerika adalah dengan didirikannya sebuah perusahaan film bernama Walt Disney Productions pada tahun 1923. Wells (2002:24) menyatakan bahwa film animasi berdurasi panjang pertama mereka adalah Snow White and the Seven Dwarfs pada tahun 1937. Berdasarkan data yang didapat dari situs resmi Academy Award, pada tahun 1938 film ini mendapatkan Special Award atas inovasi yang signifikan dan mempelopori bidang hiburan baru film animasi (Award Database n.d.).

Sejak saat itulah Disney terus memproduksi berbagai film animasi atau animasi anak-anak. Menurut Dunham dan Bergen (2009:5) hingga tahun 2008 Disney telah memproduksi 89 film animasi dan 13 film animasi lainnya bekerja sama dengan Pixar Studio yang telah ditayangkan di seluruh dunia. Menurut Zakarin (2012) Berbagai film tersebut berhasil mendapatkan kesuksesan dan disukai oleh penontonnya yaitu anak-anak.

Saat ini film animasi pun telah menjadi bagian tak terpisahkan dalam masyarakat urban. Hampir di setiap wilayah di perkotaan, memiliki bioskop yang menampilkan pertunjukan film-film animasi terutama dari Disney di setiap tahun ataupun saat masa liburan sekolah anak-anak. Gerakan feminisme di Indonesia pun saat ini semakin berkembang terutama dalam wilayah urban di mana semakin banyak perempuan modern Indonesia yang memperjuangkan hak-hak kesetaraan bagi perempuan.

\section{Latar Belakang}

Film animasi produksi Disney ditonton oleh berbagai kalangan di dunia baik anak-anak, dewasa, laki-laki, dan perempuan. Anak-anak perempuan menyukai atau mengidolakan tokoh-tokoh Disneyland terutama para Disney Princess, yaitu karakter perempuan yang menjadi sosok yang ditonjolkan dalam berbagai film animasi Disney. Berbagai merchandise Disney Princess pun banyak beredar dipasaran dan digemari oleh para penontonnya. Setiap tahunnya Disney meraih keuntungan dari penjualan berbagai merchandise karakter animasi dan film yang mereka miliki.

Dalam kisah mengenai kehidupan mereka, setiap tokohnya memiliki pergeseran karakter dan representasi feminitas yang berbeda-beda. Pergeseran yang ditampilkan ini beriringan dengan perkembangan feminisme gelombang pertama hingga feminisme gelombang ketiga saat ini. Hal ini disampaikan oleh Ebner (2009): "The more modern princesses, who arrived decades later with Ariel in The Little Mermaid in 1989, are more assertive and involved in their destiny."

Selain perubahan feminitas para Disney Princess, ada juga perubahan dari segi kultural para tokoh Disney Princess. Menurut Zakarin (2012): "The last two decades has seen the group diversify to include Persian, Native American, Chinese and African-American characters." Hal ini menjelaskan bahwa kisah para Disney Princess saat ini tidak hanya berfokus pada perempuan keturunan Kaukasian namun juga mengisahkan perjuangan para putri 
keturunan China, Afrika-Amerika, Persia, dan Native America.

Perubahan dalam karakter setiap tokoh Disney Princess ini tentu memiliki pesan atau merepresentasikan perubahan yang juga terjadi pada para perempuan di masyarakat modern sekarang ini. Berbagai perubahan itu tidak hanya berpusat pada karakter saja namun juga pada lingkungan dan berbagai hal lain yang membangun setiap kisah Disney tersebut. Meskipun begitu perlu dilihat apakah berbagai perubahan ini telah berjalan sesuai dengan perkembangan teori dan gelombang feminisme hingga saat ini.

Seiring dengan perkembangan feminisme dan kesetaraan gender, karakter para Disney Princess ini berubah semakin berani, mandiri, dan mampu menjalani petualangan untuk meraih keinginan mereka. Meskipun di permukaan Disney telah menampilkan berbagai perubahan tersebut, namun apakah sudah cukup menggambarkan realitas dan kesetaraan gender yang sesungguhnya? Karena selama ini menurut Thornham (2010:117) perempuan seringkali ditindas dalam industri film. Mereka ditindas dengan diperankan sebagai citra-citra palsu sebagai objek. Dalam hal ini yang dimaksud sebagai objek yaitu objek seks atau objek penggoda pria.

Berbagai nilai yang disampaikan dalam animasi ini memberi dampak kepada penonton dalam melihat realitas sosial terutama pada anak-anak. Dundes dalam Ellington (2009:7) menyatakan bahwa analis media telah menegaskan bahwa film-film dari perusahaan Walt Disney Production ini secara spesifik memiliki kekuatan lebih besar dalam mendidik anak-anak mengenai peran gender lebih dari pada sekolah-sekolah umum, institusi religius dan keluarga. Hal ini diperkuat oleh pernyataan dari Towbin, Haddock, Zimmerman, Lund dan Tanner dalam Ellington (2009:7), yaitu: "The Walt Disney Company is a powerhouse in contributing to children's media, particularly videos".
Towbin, Haddock, Zimmerman, Lund dan Tanner dalam Ellington (2009:7) menyatakan bahwa berdasarkan penelitian terbaru, anak-anak menonton film-film Disney secara berulang. Rata-rata anakanak menonton dua setengah sampai tiga jam televisi setiap hari, dan dalam penelitian tersebut tercatat bahwa anakanak juga menonton film yang mereka miliki secara berulang seperti film televisi. Jadi, secara teori, anak-anak menonton film-film Disney sekitar dua setengah hingga tiga jam perhari. Hal ini menunjukkan bahwa film-film animasi Disney memiliki kekuatan yang besar dalam mempengaruhi dan membentuk pandangan anak-anak mengenai feminitas.

\section{Formulasi Masalah}

Berdasarkan penjabaran di atas, dibutuhkan analisa komprehensif dan mendalam dari berbagai film animasi Disney Princess mengenai perubahan representasi feminitas sejak awal kemunculan hingga saat ini. Penelitian terutama berfokus pada unsur feminitas yang diwakili oleh penggambaran tentang tubuh, rambut, kulit, suara, gerakan, emosi, ambisi, dan peran yang merupakan refleksi dari realitas kehidupan sehari-hari.

Penulis memformulasikan masalah penelitian yaitu:

1) Bagaimana penggambaran feminitas karakter Disney Princess?

2) Bagaimana penggambaran peran wanita di wilayah publik yang diperlihatkan oleh karakter-karakter Disney Princess?

3) Bagaimana pergeseran representasi feminitas para karakter wanita dalam film animasi Disney Princess?

Film yang diteliti merupakan film pertama hingga terakhir yang memiliki karakter Disney Princess di dalamnya, yaitu sejak tahun 1937-2012, dimana pada jangka waktu tersebut terdapat 11 judul film. Penelitian ini tidak mengambil film animasi pendek (spin-off) Disney Princess 
ataupun sekuel dari film animasi Disney Princess yang sudah ada. Hal ini dikarenakan umumnya sekuel yang dibuat hanya didistribusikan langsung ke layar televisi rumah melalui Video atau DVD dan bukan melalui bioskop.

\section{Tujuan}

Tujuan penelitian ini adalah sebagai berikut:

1) Untuk mengetahui penggambaran feminitas karakter Disney Princess

2) Untuk mengetahui penggambaran peran wanita di wilayah publik yang diperlihatkan oleh karakter-karakter Disney Princess

3) Untuk mengetahui apakah pergeseran representasi feminitas dalam film animasi Disney Princess sejalan dengan perubahan gelombang feminisme

\section{Sistematika Penulisan}

Penelitian ini terdiri dari lima bagian yaitu yang pertama adalah pendahuluan, dimana pada bab ini berisi mengenai latar belakang, formulasi masalah, tujuan, dan sistematika penulisan. Berikutnya pada bagian kedua berisi mengenai kajian pustaka yaitu berisi berbagai studi literatur dari penelitian yang telah ada, teori, dan konsep yang digunakan dalam penelitian ini. Pada bagian tiga yaitu mengenai metodologi penelitian dimana berisi mengenai pendekatan, metode pengumpulan data, dan metode analisis data yang digunakan dalam penelitian ini. Berikutnya pada bagian empat mengenai hasil penelitian dan analisis yang berisi tentang analisis dan hasil dari penelitian yang telah didapatkan. Pada bagian terakhir yaitu mengenai kesimpulan dari awal hingga akhir penelitian.

\section{KAJIAN PUSTAKA}

Pada tahun 2009, Malfroid melakukan penelitian dengan "judul Gender, Class, and Ethnicity in the Disney Princesses Series". Dalam penelitian ini,
Malfoid berfokus pada perubahan yang terjadi pada tokoh-tokoh Disney Princess dalam segi gender, status sosial, dan etnis. Objek penelitiannya adalah delapan tokoh Disney Princess dari Snow White hingga Mulan.

Dalam penelitian ini, Malfroid telah jelas menyebutkan objek penelitiannya hanya pada gender, status sosial, dan etnis yang terdapat dalam delapan film Disney. Sedangkan dalam penelitian ini, penulis meneliti pergeseran feminitas sebelas tokoh Disney Princess berdasarkan pada peran mereka di ruang pribadi dan ruang publik.

Penelitian ini menggunakan Teori Kritis Media Feminis sebagai dasar atau panduan penulis. Penelitian media feminis selama bertahun-tahun telah bergeser dari ketertarikan dalam mengkritisi stereotip gender ke melihat pada bagaimana penggambaran wanita dalam media dipahami oleh penonton. Menurut Hermes (McQuail, 2010:120) kita perlu memahami bagaimana media merepresentasikan gender karena konstruksi feminitas dan maskulinitas adalah bagian dari ideologi dominan. Ia juga menulis bahwa media masih menawarkan panduan dan contoh bagaimana perilaku yang umum.

Dalam kritis feminis, McQuail (2010:344) menyatakan bahwa terdapat dua isu penting yang muncul. Yang pertama adalah sejauh mana teks media yang ditujukan untuk hiburan bagi wanita (opera sabun atau roman) dapat memberikan perasaan terbebas meskipun teks tersebut mewujudkan realitas masyarakat patriarkal dan lembaga keluarga. Yang kedua adalah sejauh mana teks-teks media massa jenis baru menolak stereotip gender dan mencoba untuk memperkenalkan model peran positif dapat memiliki efek pemberdayaan bagi perempuan.

Selain itu penelitian ini juga menggunakan Teori Media dan Film Feminis yang menurut Thornham (Jackson and Jones, 2009:364) muncul atas dasar keprihatinan terhadap representasi media yang dipandang sebagai citra yang keliru 
terhadap perempuan, stereotip yang merusak persepsi diri perempuan dan membatasi peran sosial mereka. Tuchman dalam Thornham (Jackson and Jones, 2009:365) menyatakan bahwa media, pertama-tama mencerminkan nilai-nilai dominan masyarakat dalam bentuk berbagai citra atau representasi. Yang kedua, media bertindak sebagai agen sosialisasi, yang menyampaikan berbagai citra mengenai peran jenis kelamin yang distereotipkan, khususnya kepada orangorang muda. Dengan begitu, tugas kritik feminis tidak hanya ditujukan untuk membongkar cara-cara bagaimana ideologi patriarki membentuk film yang menampilkan perempuan sebagai sosok fantasi laki-laki, tetapi juga untuk mengidentifikasi berbagai kontradiksi dan keretakan internal dalam film itu sendiri yaitu titik-titik dimana film menunjukkan usahanya untuk memaksakan maknamakna patriarkal pada tokoh-tokoh perempuannya.

Sedangkan konsep yang digunakan dalam penelitian ini terutama adalah Tiga Gelombang Feminisme dan Feminitas. Menurut Sanders (Gamble 2010:20) feminisme muncul diawali dengan sebuah tulisan karya Wollstonescraft yang secara garis besar tidak mempertimbangkan hilangnya peran mereka dari wilayah domestik; dan tuntutannya yang paling radikal adalah hak pilih. Berikutnya adalah feminisme gelombang kedua yang enurut Thornham (Thornham 2010:38) mengisyaratkan adanya fokus ganda yang menandai gerakan ini: pada perempuan sebagai kelompok sosial yang tertindas dan pada tubuh perempuan dengan kebutuhan atas otonomi seksual sebagai sasaran mendasar dari penindasan tersebut. Sedangkan menurut Krolokke dan Sorensen (2006:10): "In the early phase, radical second-wave feminisms were characterized by a claim for sisterhood and solidarity". Solidaritas ini, menurut Hollows (2010:5) ditandai dengan adanya berbagai protes terhadap pelaksaan kontes kecantikan dan juga pendirian berbagai organisasi wanita seperti NOW (National
Organization for Women), Women's Liberation di Amerika.

Berbagai aktivitas feminisme gelombang kedua membawa banyak perubahan bagi kesetaraan perempuan di masyarakat. Berbagai perubahan itu kemudian membawa kita pada feminisme gelombang ketiga. Feminisme gelombang ketiga ini melihat perempuan sebagai sosok agen sosial yang mampu, kuat, dan lebih tegas -bahkan agresif- namun juga lebih menyenangkan.

Menurut Krolekke dan Sorensen (2006:19), feminisme gelombang ketiga terikat dengan efek dari globalisasi dan redistribusi kekuasaan yang kompleks. Hal ini juga mencerminkan diversifikasi kepentingan dan perspektif perempuan dan pemecahan masalah utama mengenai penindasan dan pembebasan. Selain itu, menurut Halberstam dalam Krolekke dan Sorensen (2006:19): "They call for recognition of queers: not only gays and lesbians but also drag queens, drag kings, transsexuals, masculine women, and feminine men."

Jika dilihat dari penjabaran mengenai gelombang feminime di atas, maka perempuan tidak lepas dari bagaimana ia ditampilkan. Perempuan harus feminin atau menunjukkan ciri feminitas. Secara sederhana feminitas adalah ciri yang harus dimiliki setiap anak perempuan. Menurut Wijngaarg (1997:5): "Femininity is a set of attributes, behaviors, and roles generally associated with girls and women. Femininity is often perceived as a social construct, which is made up of both socially defined and biologically created factors."

Berdasarkan pernyataan di atas, kita dapat melihat bahwa feminitas merupakan konstruksi yang diciptakan berdasarkan faktor sosial dan faktor biologis. Perempuan atau wanita dianggap harus memiliki feminitas yang sesuai dan pantas. Hal ini menurut Hollows (2010:4) menyebabkan feminitas dianggap sebagai nilai dan perilaku feminin yang dipandang sebagai penyebab utama penindasan yang dialami perempuan. Sedangkan dalam 
bukunya, Brownmiller (2013) menyatakan bahwa feminitas dapat dilihat dalam beberapa kategori yaitu tubuh, rambut, pakaian, suara, kulit, gerakan, emosi, dan ambisi.

\section{METODOLOGI PENELITIAN}

Penelitian ini menggunakan paradigma kritis karena ingin melihat bagaimana perempuan ditampilkan dalam film-film animasi Disney Princess, yang mungkin didalamnya terdapat representasi yang tidak nyata mengenai perempuan akibat dominasi dan ketidaksetaraan terhadap perempuan. Yasir (2012:13) menyatakan bahwa secara khusus paradigma kritis bertujuan untuk menginterpretasikan dan karenanya memahami bagaimana berbagai kelompok sosial dikekang dan ditindas.

Dalam penelitian ini, penulis akan meneliti teks dan konteks dari film-film animasi Disney Princess bersama-sama. Teks yang diteliti adalah dialog, ucapan, musik, dan gambar. Sedangkan konteknya akan dikaitkan dengan situasi kapan film tersebut diproduksi, dan situasi perkembangan femisnime saat itu. Selain itu model analisis yang digunakan adalah model analisis Sara Mills.

Penulis melakukan analisa data sesuai dengan urutan sebagai berikut:
1) Melakukan observasi terhadap 11 judul film animasi Disney Princess, yaitu:

a. Snow White and The Seven Dwarfs (Snow White)

b. Cinderella (Cinderella)

c. Sleeping Beauty (Aurora)

d. The Little Mermaid (Ariel)

e. Beauty and The Beast (Belle)

f. Aladdin (Jasmine)

g. Pocahontas (Pocahontas)

h. Mulan (Mulan)

i. The Princess and The Frog (Tiana)

j. $\quad$ Tangled (Rapunzel)

k. Brave (Merida)

2) Memasukkan hasil observasi ke dalam tabel hasil penelitian sesuai dengan delapan unsur feminitas

3) Membuat kategori hasil analisa

4) Menentukan posisi setiap karakter Disney Princess dengan melihat bagaiman mereka ditampilkan dalam setiap film

5) Menentukan posisi pembaca dengan melihat perkembangan gelombang feminisme yang sejalan dengan munculnya film animasi Disney Princess

\section{HASIL PENELITIAN DAN ANALISIS}

Secara singkat, tabel data hasil penelitian disajikan pada Tabel 1 dan 2 .

Tabel 1. Data Hasil Temuan Fisik

\begin{tabular}{|c|c|c|}
\hline Disney Princess & Era & Tampilan Fisik \\
\hline Snow White & $\begin{array}{c}\text { Klasik } \\
(1937-1960) \\
\text { Feminisme gelombang pertama }\end{array}$ & $\begin{array}{l}\text { Berkulit putih, rambut hitam, } \\
\text { tubuh ramping }\end{array}$ \\
\hline Cinderella & & $\begin{array}{l}\text { Berkulit putih, rambut pirang, } \\
\text { tubuh ramping }\end{array}$ \\
\hline Aurora & & $\begin{array}{l}\text { Berkulit putih, rambut pirang, } \\
\text { tubuh ramping }\end{array}$ \\
\hline Ariel & $\begin{array}{c}\text { Renaissance } \\
(1960-1998) \\
\text { Feminisme gelombang kedua }\end{array}$ & $\begin{array}{l}\text { Berkulit putih, rambut merah, } \\
\text { tubuh ramping }\end{array}$ \\
\hline Belle & & $\begin{array}{l}\text { Berkulit putih, rambut cokelat, } \\
\text { tubuh ramping }\end{array}$ \\
\hline Jasmine & & $\begin{array}{l}\text { Berkulit cokelat, rambut hitam, } \\
\text { tubuh ramping }\end{array}$ \\
\hline Pocahontas & & $\begin{array}{l}\text { Berkulit cokelat, rambut hitam, } \\
\text { tubuh ramping }\end{array}$ \\
\hline Mulan & Modern & Berkulit kuning, rambut hitam, \\
\hline
\end{tabular}




\begin{tabular}{lcc}
\hline Disney Princess & Era & Tampilan Fisik \\
\hline Tiana & $\begin{array}{c}(1998-\text { sekarang }) \\
\text { Feminisme gelombang ketiga }\end{array}$ & $\begin{array}{c}\text { Berkulit hitam, rambut hitam, } \\
\text { tubuh ramping }\end{array}$ \\
Rapunzel & $\begin{array}{c}\text { Berkulit putih, rambut pirang, } \\
\text { tubuh ramping }\end{array}$ \\
Merida & $\begin{array}{c}\text { Berkulit putih, rambut merah, } \\
\text { tubuh ramping }\end{array}$ \\
\hline
\end{tabular}

Tabel 2. Data Hasil Temuan mengenai karakter non-fisik Disney Princess

\begin{tabular}{|c|c|c|}
\hline Disney Princess & Era & Peran \\
\hline Snow White & $\begin{array}{c}\text { Klasik } \\
(1937-1960) \\
\text { Feminisme gelombang } \\
\text { pertama }\end{array}$ & Domestik, mengerjakan pekerjaan rumah tangga \\
\hline Cinderella & & Domestik, mengerjakan pekerjaan rumah tangga \\
\hline Aurora & & Domestik, mengerjakan pekerjaan rumah tangga \\
\hline Ariel & $\begin{array}{l}\text { Renaissance } \\
(1960-1998) \\
\text { Feminisme gelombang } \\
\text { kedua }\end{array}$ & $\begin{array}{c}\text { Penyanyi utama kerajaan, memiliki keinginan untuk } \\
\text { bertualang di dunia manusia }\end{array}$ \\
\hline Belle & & $\begin{array}{l}\text { Domestik, mengerjakan pekerjaan rumah tangga } \\
\text { namun memiliki keinginan untuk pergi dari kota } \\
\text { tempat ia tinggal }\end{array}$ \\
\hline Jasmine & & $\begin{array}{l}\text { Putri penerus kerajaan, diharapkan segera menikah } \\
\text { dan memiliki keturunan, namun menolak } \\
\text { perjodohan dan mencoba keluar dari istana }\end{array}$ \\
\hline Pocahontas & & $\begin{array}{l}\text { Penerus kepala suku Indian, diharapkan segera } \\
\text { menikah, namun memiliki keinginan untuk melihat } \\
\text { dunia luar. }\end{array}$ \\
\hline Mulan & $\begin{array}{l}\text { Modern } \\
(1998 \text { - sekarang }) \\
\text { Feminisme gelombang } \\
\text { ketiga }\end{array}$ & $\begin{array}{c}\text { Peran domestik, mengerjakan pekerjaan rumah } \\
\text { tangga, diharapkan segera menikah. Namun karena } \\
\text { kondisi, terpaksa menyamar sebagai tentara pria dan } \\
\text { berjuang menyelamatkan China. }\end{array}$ \\
\hline Tiana & & $\begin{array}{c}\text { Pelayan restoran, berkeinginan untuk memiliki } \\
\text { restoran sendiri. }\end{array}$ \\
\hline Rapunzel & & $\begin{array}{l}\text { Peran domestik, mengerjakan berbagai pekerjaan } \\
\text { rumah tangga, namun ingin keluar dari menara } \\
\text { tempat ia dikurung. Setelah berhasil keluar, kembali } \\
\text { menjadi Putri penerus kerajaan. }\end{array}$ \\
\hline Merida & & $\begin{array}{l}\text { Tidak menyukai pekerjaan rumah tangga dan peran } \\
\text { sebagai putri kerajaan. Menolak ketika dijodohkan. }\end{array}$ \\
\hline
\end{tabular}

\section{Analisa Mikro}

Berikut adalah kategori yang didapatkan dalam analisa mikro, yaitu:

1) Kecantikan Semu

Berdasarkan data penelitian, para Disney Princess secara fisik ditampilkan cukup beragam dari segi warna rambut dan warna kulit. Sebagian besar Disney Princess memiliki jenis kulit putih yang menurut Brownmiller $(2013,145)$ memang dianggap feminin dan sering dipuji. Dari segi warna rambut berdasarkan hasil yang didapatkan, warna hitam justru lebih mendominasi dibandingkan warna pirang yang menurut Brownmiller (2013, 71-72) baik di Amerika maupun Eropa, rambut pirang (blonde) dianggap mewakili atribut feminin. Begitu pula dengan penggambaran warna kulit para Disney Princess yang cukup bervariatif yaitu putih (Snow White, Aurora, Cinderella, Ariel, Belle, Rapunzel, dan Merida), kuning (Mulan), cokelat (Pocahontas dan Jasmine), serta hitam (Tiana). 
Berikutnya jika dilihat dari bentuk tubuh, berdasarkan data yang didapatkan, hampir keseluruhan karakter Disney Princess digambarkan dengan bentuk tubuh ideal meskipun pada realitasnya tidak semua perempuan memiliki bentuk tubuh seperti ini. Kilbourne dalam Murnen dan Seabrook (2012, 439) mengkritik bahwa tubuh kurus yang dianggap ideal disajikan dalam iklan sejak tahun 1970-an dan menunjukkan bahwa yang tubuh kurus berdampingan dengan citra dominasi pria dan pembungkaman terhadap perempuan. Misalnya, seorang pria mungkin lebih tinggi dari perempuan untuk menunjukkan dominasinya di dalam iklan. Dengan demikian, citra tubuh kurus berdampingan dengan citra subordinasi lainnya.

2) Inferioritas Fisik Perempuan

Dalam unsur ini, terlihat pergeseran yang signifikan mulai dari film pertama (Snow White and the Seven Dwarfs) hingga film terakhir (Brave). Karena jika dikaitkan dengan pendapat Brownmiller (2013, 196) bahwa seorang perempuan harus bergerak secara halus, lemah lembut, perlahan bagai air yang mengalir hanya tergambarkan secara jelas pada karakter Disney Princess di film-film awal.

3) Feminine Traits / Ciri Feminin

Karakter Disney Princess tidak lepas dari penggambaran perempuan feminin atau yang dipaksa untuk tampil feminin. Hal ini terlihat dari pakaian, kemampuan untuk bernyanyi, dan keberanian untuk mengungkapkan pendapat. Hampir seluruh karakter Disney Princess memakai gaun ataupun rok dalam film mereka. Karakter para putri dengan pakaian cantik dan gaun masih menjadi bagian besar dalam ciri feminin, meskipun pada realitasnya perempuan saat ini tidak bergantung pada pakaian seperti itu. Sedangkan mengenai suara dan keberanian untuk mengungkapkan pendapat cukup mengalami pergeseran yang cukup baik. Dari perempuan yang diam saja menerima perlakukan dari lingkungannya, menjadi perempuan yang bisa mengutarakan pendapat dan keinginannya.

\section{4) Damsel in Distress}

Damsel in Distress adalah sebuah istilah klasik dalam dunia literatur, seni, film, dan video game untuk menyebutkan karakter perempuan muda yang berada dalam keadaaan sulit dan membutuhkan pahlawan pria untuk menyelamatkannya. Setelah diselamatkan, biasanya karakter perempuan akan menikahi sang pahlawan tersebut. Biasanya karakter seperti ini memiliki berbagai masalah atau keadaan yang tidak dapat ia selesaikan sendiri. Di periode awal film Disney Princess, hampir seluruh karakternya hanya pasrah dan mengikuti keadaan mereka. Tokoh-tokoh Disney Princess di era awal memang selalu diam dan menunggu pertolongan dari Pangeran ataupun Ibu Peri. Namun semakin berkembangnya jaman, pergeseran kemandirian Disney Princess cukup ditampilkan dengan baik meskipun masih ada campur tangan dan bantuan dari tokoh pria dalam film-film tersebut, kecuali dalam film Brave dimana Merida berusaha untuk menyelesaikan masalahnya sendiri.

\section{5) Ketidakseimbangan Emosi}

Perempuan sering ditampilkan lemah secara emosi dalam media. Salah satu cirinya adalah dilihat dari seberapa mudah karakter Disney Princess menangis dan jatuh cinta dalam film-film mereka. Meskipun Disney Princess digambarkan semakin mandiri dan kuat, namun selalu ada bagian di dalam setiap film dimana hampir setiap Disney Princess pernah ditampilkan menangis ketika menghadapi masalah.

Selanjutnya, dalam penelitian ini, penulis ingin memasukkan satu unsur penting yang berkaitan dengan ketidakseimbangan emosi yaitu betapa mudahnya para tokoh Disney Princess mengalami jatuh cinta dengan karakter pria dalam film-film mereka. Dalam penelitiannya, Sawyer (2014: 6) menyatakan bahwa: "Disney films do not show the process of falling in love. For them it is a very instant reaction that means it will be lasting love." Yaitu sering terdengar kritikan mengenai karakter 
Disney Princess yang mudah sekali jatuh cinta. Mereka bertemu dengan pangeran, bernyanyi bersama, dan saling jatuh cinta untuk selamanya

\section{6) Tuntutan Peran Domestik}

Tuntutan perempuan sebagai pemegang peran domestik rumah tangga perlahan-lahan ditampilkan bergeser dalam berbagai film animasi Disney Princess. Karakter para putri tersebut yang awalnya selalu mengerjakan pekerjaan rumah tangga, berubah menjadi petualang, pemersatu suku, pemilik usaha, hingga penyelamat kerajaan. Meskipun begitu, kesetaraan peran domestik antara karakter pria dan perempuan dan film-film tersebut belum tergambarkan dengan jelas. Tidak ada satupun film Disney Princess yang menampilkan karakter atau tokoh pria yang bekerja sama atau memiliki peran setara dalam tanggung jawab domestik. Padahal tuntutan utama dalam feminisme adalah kesetaraan antara pria dan perempuan dalam berbagai bidang.

7) Defisien Ambisi

$$
\text { Brownmiller (2013, 258) }
$$

menyatakan bahwa feminitas memperbolehkan untuk tidak mengikuti ambisi, seperti sebuah strategi kamuflase yang baik bagi mereka yang ingin menyembunyikan ambisi dari pandangan publik. Bagaimanapun juga memiliki sebuah ambisi bukanlah ciri feminin. Para Putri dalam Disney Princess generasi awal menunjukkan karakter yang tidak memiliki ambisi pribadi. Snow White misalnya yang menerima saja dijadikan pelayan di istananya oleh ibu tirinya, Sang Ratu. Begitupula dengan Cinderella yang juga mengikuti keinginan Ibu Tiri dan dua orang saudari tirinya untuk menjadi pelayan di rumahnya sendiri. Sedangkan Aurora menurut saja saat ia diharuskan menikah dengan Pangeran yang telah dijodohkan dengannya.

Kepemilikan terhadap ambisi mulai ditampilkan oleh para putri di tahun-tahun 1970-1990an dimana keinginan mereka mulai berkembang dan dihiasi dengan petualangan, meskipun pada akhirnya keinginan untuk bersama dengan orang yang mereka cintai ataupun menikah tetap ditampilkan. Ariel misalnya ingin sekali tinggal di dunia manusia. Belle yang menyukai buku karena ambisinya untuk melihat dunia luar, begitu pula dengan Jasmine. Pocahontas yang ingin menyatukan sukunya dengan pendatang, serta Mulan yang ingin melindungi sang ayah dan nama baik keluarga dengan menyamar sebagai pria.

Ambisi semakin terpancar dalam karakter Disney Princess generasi tahun 2000an dimana mereka tidak sekedar memiliki keinginan seputar kehidupan keluarga atau petualangan, namun mereka memiliki ambisi nyata lainnya. Tiana misalnya memiliki keinginan besar untuk memiliki restoran sendiri meskipun dalam film tersebut ia digambarkan sebagai perempuan kalangan bawah. Selanjutnya adalah Rapunzel yang sejak awal cerita sudah berani mengungkapkan keinginan besarnya untuk keluar dari menara kurungannya dan melihat lampion terbang kepada Mother Gothel. Terakhir adalah Merida dalam film Brave yang ditampilkan memiliki keinginan untuk hidup bebas. Ia ingin memilih kehidupannya sendiri, memilih pasangannya sendiri. Apa yang digambarkan lewat Merida dapat dianggap cukup mewakili bagaimana seharusnya perempuan ditampilkan di media sesuai dengan hasil wawancara dengan Gadis Arivia yang menyatakan:

Kita harusnya ditampilkan sebagai perempuan yang berdaya. Perempuan yang bisa memutuskan hidup dia. Perempuan yang tidak memiliki guilty feeling kalau memilih karir dan bukan keluarga. Perempuan yang bisa menentukan pernikahannya, calonnya, dan sebagainya.

Merida memang ditampilkan sebagai perempuan yang berdaya dan vokal memperjuangkan keinginannya untuk dapat memilih jalan hidupnya sendiri. Namun penulis menyayangkan dalam film Brave tersebut, Merida ditampilkan sebagai perempuan rebel atau pemberontak. 


\section{Analisa Makro}

Berdasarkan analisa secara mikro, dapat disimpulkan bahwa tampilan feminitas dari segi fisik cukup bervariasi dalam segi warna rambut dan warna kulit. Namun jika dilihat dari segi makro, pergeseran representasi feminitas kurang berjalan sesuai dengan perkembangan feminisme itu sendiri. Black Feminism pertama misalnya sebenarnya sudah terjadi sejak tahun 1831 dan diusung kembali di tahun 1960an, namun munculnya karakter Disney Princess berkulit hitam baru ada di tahun 2008 yaitu dalam era modern Disney yang dimulai sejak tahun 1998. Selain itu ada gerakan Fat Feminism atau Fatpositive Feminism yang menurut Stimson (2008) muncul pertama kali di akhir tahun 1960 ketika gelombang feminisme ke dua berjalan yang mempromosikan penerimaan perempuan segala ukuran. Namun nampaknya gerakan ini tidak memberikan kontribusi berarti pada penggambaran karakter Disney Princess yang hampir semuanya bertubuh kurus atau ramping dengan ukuran pinggang yang kecil.

Sedangkan untuk unsur feminin non-fisik, ada pergeseran yang terjadi terutama dalam segi ambisi dan peran. Disney Princess di era feminisme gelombang pertama misalnya yaitu Snow White, Cinderella, dan Aurora ditampilkan sesuai dengan bagaimana perempuan di masa itu yaitu hanya memiliki peran domestik. Dalam feminisme gelombang pertama tersebut, ide yang diusung adalah hak pilih dalam politik. Hal ini tentunya sulit untuk dimasukkan ke dalam kisahkisah Disney Princess era awal yang memang diadaptasi langsung dari dongeng-dongeng lama.

Sedangkan di era feminisme gelombang ke-dua, ide yang diusung terutama adalah kesetaraan dalam berbagai bidang dan solidaritas sesama perempuan. Sayangnya perkembangan feminisme di era ini tidak terlalu ditampilkan dalam diri karakter Disney Princess yang muncul pada jaman tersebut yaitu Ariel, Belle, dan Jasmine. Memang karakter tersebut ditampilkan lebih mandiri dan memiliki keinginan untuk keluar dari tuntuan domestik, namun mereka masih diselamatkan atau membutuhkan pria untuk menolong mereka keluar dari masalah. Sisi solidaritas-pun dapat dikatakan tidak terlihat sama sekali dalam film-film Disney Princess tersebut.

Selanjutnya di era feminisme gelombang ke-tiga, karakter Disney Princess yang muncul adalah Pohacontas, Mulan, Tiana, Rapunzel, dan Merida. Jika dilihat secara mikro, ada pergeseran yang cukup signifikan dalam karakter pada Disney Princess tersebut. Mereka lebih mandiri, lebih berani, dan memiliki keinginan lebih terhadap hidup mereka. Meskipun pergeseran feminitas ini berjalan beriringan dengan perkembangan feminisme, namun pada akhirnya tidak ada sisi perjuangan feminisme di gelombang ke-tiga yang masuk dalam cerita-cerita tersebut seperti pengakuan terhadap lesbian dan queer. Hal ini kemungkinan besar tidak ditampilkan karena belum sesuai untuk penonton usia anak-anak.

\section{KESIMPULAN}

Hasil penelitian menunjukkan bahwa ada pergeseran bagaimana karakter Disney Princess ditampilkan dalam film. Unsur-unsur feminitas seperti tampilan fisik untuk kulit dan rambut misalnya ditampilkan cukup beragam dan tidak memiliki standar tertentu. Namun sayangnya untuk tampilan bentuk tubuh masih mengacu pada standar bahwa perempuan harus bertubuh kurus, lebih kecil dari pria, dan berpinggang kecil. Meskipun pada realitasnya, tidak semua perempuan memiliki bentuk tubuh seperti ini. Selain itu penggambaran bentuk tubuh ini tidak berjalan sesuai dengan berbagai gerakan feminisme seperti Fat-positive feminism yang menyarankan penerimaan terhadap perempuan dengan bentuk tubuh dengan segala ukuran.

Selain itu jika dilihat dari sisi peran dan ambisi, juga mengalami pergeseran yang cukup signifikan meskipun pergeseran tersebut dirasa ada yang tidak berjalan sesuai perkembangan teori-teori 
dan gerakan feminisme hingga saat ini. Pergeseran karakter perempuan dalam animasi Disney Princess belum sepenuhnya mewakili atau merepresentasikan perkembangan yang terjadi dalam dunia feminisme saat ini seperti kemandirian dan kesetaraan antara pria dan wanita. Disney Princess yang muncul dalam era modern ditampilkan sebagai perempuan pemberontak.

Sebagai film yang ditonton oleh banyak penonton anak dan dapat menjadi panutan atau contoh terutama untuk anak perempuan, film animasi Disney seharusnya dapat memberikan penggambaran kesetaraan antara laki-laki dan perempuan baik dalam wilayah privat maupun wilayah publik seperti pekerjaan dan pendidikan. Selain itu karena perkembangan feminisme terus berjalan dan semakin banyak film animasi terutama produksi Disney yang akan muncul, maka sebaiknya dilakukan penelitian lanjutan terhadap film baru baik menggunakan metode wacana kritis yang sama ataupun berbeda seperti Fairclough yang juga menganalisa bagaimana sebuah teks diproduksi.

\section{DAFTAR PUSTAKA}

1. Ardianto, Elvinaro, Lukiati Komala, and Siti Karlinah. Komunikasi Massa Suatu Pengantar. Bandung: Simbiosa Rekatama Media, 2007.

2. Award Database. n.d. http://awardsdatabase.oscars.org/ampas _awards/Display

Main.jsp?curTime $=1361115564359$ (accessed Februari 8, 2013).

3. Brownmiller, Sarah. Femininity. New York City: Open Road, 2013.

4. Ebner, Sarah. Is The Princess Stereotype Harming Our Daughters? Agustus 2009, 2009. http://www.thetimes.co.uk/tto/life/fami lies/article1758596.ece (diakses Agustus 22, 2012).

5. Dominick, Joseph R. The Dynamic of Mass Communication Media in
Transition Eleventh Edition. New York: McGraw-Hill, 2011.

6. Dunham, M L, and Lara Bergen. Disney Junior Encyclopedia of Animated Characters: Including Characters from Your Favorite Disney*Pixar Films. California: Disney Press, 2009.

7. Ellington, Emily Sear. "Is Disney Surfing the Third Wave? A Study of the Depiction of Womanhood in Disney's Female Protagonist." 2009.

8. Gamble, Sarah. Pengantar Memahami Feminisme dan Postfeminisme. Yogyakarta: Jalasutra, 2010.

9. Hollows, Joanne. Feminisme, Feminitas, dan Budaya Populer. Yogyakarta: Jalasutra, 2010.

10. Jackson, Stevi, and Jackie Jones. Teori-Teori Feminis Kontemporer. Yogyakarta: Jalasutra, 2009.

11. Krolokke, Charlotte, and Ann Scott Sorensen. Gender Communication Theories and Analyses: From Silence to Performance. California: SAGE, 2006.

12. Malfroid, Kirsten. "Gender, Class, and Ethnicity in the Disney Princesses Series." 2010.

13. McQuails, Denis. Mass Communication Theory 6th Edition. London: SAGE, 2010.

14. Murnen, SK, and R Seabrook. "Feminist Perspectives on Body Image and Physical Appearance." Encyclopedia of Body Image and Human, 2012: 438-443.

15. Sawyer, Nicole. "Feminist Outlooks at Disney Princess's." 2014: 6.

16. Stimson, Karen. largesse. May 12, 2008.

http://www.largesse.net/feminism.html (diakses November 6, 2016). 
17. Thornham, Sue. Teori Feminis dan Cultural Studies. Yogyakarta: Jalasutra, 2010.

18. Wells, Paul. Animation: Genre and Authorship. London: Wallflower Press, 2002.

19. Wijngaard, Marianne van den. Reinventing the Sexes: The Biomedical Construction of Femininity and Masculinity. Bloomington: Indiana University Press, 1997.

20. Yasir. "Paradigma Komunikasi Kritis: Suatu Alternatif Bagi Ilmu Komunikasi." Jurnal Ilmu Komunikasi, 2012: 1-55.

21. Zakarin, Jordan. Hollywood Reporter. 2012. http://www.hollywoodreporter. com/news/pixar-brave-merida-disneyprincess-feminist-341124 (diakses Agustus 22, 2012). 